\title{
ASSESSMENT OF RESULTS OF REORGANIZATION OF LAND RELATIONS IN BALTIC STATES
}

\author{
Velta Parsova ${ }^{1}$, Dr.oec.; Anda Jankava², Dr.oec., Siim Maasikamae ${ }^{3}$, Ph.D.(cand. oec.), \\ Audrius Aleknavicius ${ }^{4}$, Doctor of technology sciences \\ ${ }^{1,2}$ Latvia University of Life Sciences and Technologies, ${ }^{3}$ Estonian University of Life Sciences, ${ }^{4}$ Vytautas Magnus \\ University, Lithuania
}

\begin{abstract}
After the collapse of Soviet system, immediately after declaration of independence, Estonia, Latvia and Lithuania decided to initiate land reform within the framework of agrarian reform. The defined general objectives of land reform were: to establish a fairer system of property and use rights, to create conditions for intensity and productivity increasing of land use, to strengthen the rights of lessors and tenants, to grant land to those who wish to cultivate or otherwise use the land. However, the legislation and administrative systems of separate Baltic States were different, so the objectives and tasks of land reform, as well as the measures and methods for implementing the land reform, were different.

The aim of the article is to compare and evaluate the land ownership reform processes in Estonia, Latvia and Lithuania, to analyse their legal security, the objectives, tasks, process and procedures of the reform, as well as the results obtained. In order to find out the situation and to make comparative judgments and conclusions, in research mainly document analysis and monographic or descriptive method haves been used.

The positive role of land reform in all Baltic States is the restoration of land ownership, which has led to more targeted and intensive use of land in agriculture and other sectors. Land reform has created the preconditions for initiative and action of landowners in market economy. An additional effect is the development and implementation of state-of-the-art real estate registration systems in administration of each state. The article also analyses the shortcomings and problems encountered during the reform.
\end{abstract}

Key words: Baltic States, Land Ownership, Land Reform, Land Use, Land Management.

JEL code: Q15; Q24.

\section{Introduction}

At this moment, 30 years have passed since collapse of the Soviet Union. Change of political situation always is one of the main challenges for rearrangement of land ownership and land use forms within new socio-economic circumstances. Therefore, in all former soviet republics, as well as in former socialist countries in Eastern Europe, has started re-organisation of land relations - land reforms. Land reform is one of the means of legal changes of the structure of land ownership. General defined key objectives of land reform are:

- to establish fairer distribution of ownership and land use rights;

- to secure rights of leaseholders;

- to increase the intensity and productivity of land use;

- to give the land to persons who need it (Auzins A., 2008).

However, the objectives and tasks, as well as process of land reform can vary from country to country, depending on public administration system, existing structure of land ownership, social situation and other circumstances. Estonia, Latvia and Lithuania - neighbours at the Baltic Sea, at beginning of reform had similar land use situation due to similar geographical conditions and unified management system in frame of soviet system. As it can be seen in Table 1, there are no significant differences in total area and population between these three countries.

Lithuania has the largest proportion of agricultural land, while Estonia and Latvia have relatively larger area of forests.

\footnotetext{
${ }^{1}$ Velta Parsova e-mail: velta@parsova.Iv; anda.jankava@llu.Iv

${ }^{3}$ Siim Maasikamae e-mail: siim.maasikamae@emu.ee

3 Siim Maasikamae e-mail: siim.maasikamae@emu.ee

4 Audrius Aleknavicius email: audrius.aleknavicius@vdu.It
} 
Rearrangement of the economy at the end of the 1980-s, understanding of certain shortcomings in the management of former large agricultural enterprises, an idea that private initiative could solve these problems, as well as principles of self-financing became more and more popular in society. It determined that, still being under soviet legislation, simultaneously in all three Baltic Republics there were accepted appropriate legislative acts on transfer of the land to individual management:

- in Estonia - the Farmers' Holdings Act (adopted on 06.12.1989) (Eesti NSV taluseadus, 1989);

- in Latvia - the law "On peasant farms in Latvian Soviet Socialist Republic" (adopted on 18.05.1989) (Par zemnieku saimniecibam ..., 1989);

- in Lithuania - the law "On Farmer's Farm" (adopted on 04.07.1989) (Aleknavicius, 2008).

Table 1

Features characterising the territory, population and land use in the Baltic States (on 01.01.2019)

\begin{tabular}{|c|c|c|c|}
\hline Indicators & Estonia & Latvia & Lithuania \\
\hline Territory of country, million ha & 4.52 & 6.46 & 6.53 \\
\hline Population, million people & 1.33 & 1.91 & 2.79 \\
\hline Population density, inhabitants per square km & 29.4 & 29.5 & 42.8 \\
\hline \multicolumn{4}{|c|}{ Types of land use, $\%:$} \\
\hline agriculture land & 30 & 36 & 52 \\
\hline forests & 53 & 48 & 33 \\
\hline swamps & 7.8 & 3 & 2 \\
\hline under water & 2.2 & 4 & 4 \\
\hline under buildings and yards & 2.3 & 2 & 3 \\
\hline under roads & 1.2 & 2 & 2 \\
\hline
\end{tabular}

Source: author's calculations based on data of national cadastre information system and national statistics of Estonia, Latvia and Lithuania

These decisions led to the transition from centralised planned economy to the market economy, followed by the change of exclusive public ownership to land and other means of production to private ownership. By adopting these laws, the land remained in exclusive ownership of the State, but members of large collective farms were able to establish peasant farms - to receive the land in permanent use with the right to inherit it. Agricultural machinery and other means of production, as well as residential and production buildings could be owned by new subjects - farmers.

This meant that the law extended the range of objects that could be in private ownership. Establishment of such peasant farms conformed to the political, economic and social situation at this time, and this really created preconditions for further conversion of state ownership. The land to new formations was separated from large collective farms (kolkhozes and sovkhoses). Demand for land was high and number and area of established peasant farms increased very fast (Table 2).

These decisions played very important role, both positive and negative, in further processes of land reform. Strong willingness to create individual farms (households) played an important role in identifying of problems and solutions of following land reform. However, creating these individual farms interests of former landowners (until 1940) and boundaries of their households were not respected, because in this period in frame of soviet system the question of restitution of ownership rights to former owners was not even considered. This situation created one of the challenges in further processes of reorganisation of land relations. 
Development of peasant farms in Estonia, Latvia and Lithuania (1990 - 1993)

\begin{tabular}{|l|c|c|c|c|c|}
\hline \multirow{2}{*}{ Indicators } & \multicolumn{2}{c|}{ Estonia } & \multicolumn{2}{c|}{ Latvia } & Lithuania \\
\cline { 2 - 6 } & $\mathbf{1 9 9 1}$ & $\mathbf{1 9 9 3}$ & $\mathbf{1 9 9 0}$ & $\mathbf{1 9 9 1}$ & $\mathbf{1 9 9 2}$ \\
\hline Number of peasant farms, thousand & 7.0 & 10.2 & 7 & 10 & 5.14 \\
\hline Total area of peasant farms, ha & 176.7 & 252.2 & 152 & 186 & 86.4 \\
\hline Average area of peasant farm, ha & 25.1 & 24.8 & 21.7 & 18.6 & 16.8 \\
\hline
\end{tabular}

Source: author's calculations based on (Aleknavicius P., 2008; Jurgenson, E., 2016; Zemes reformai Latvija..., 2000)

Fundamental changes in ownership relations started after the restoration of independence in 1991, when land reform began in all three Baltic States. Implementation of land reform was preceded by adoption of first legislative acts, followed by many other laws and regulations.

The aim of the article is to evaluate the processes of restructuration of land ownership rights in Baltic States, to analyse their legal background, objectives and tasks of reform, progress of process and procedures, as well as its results and to make comparisons between them.

In order to clarify the situation and to carry out comparative judgments and conclusions, the study has applied a method of analysis of documents and a monographic or descriptive study. The study summarises the studies published previously by the authors of the article and other researchers on the progress and results of land reform in the relevant countries, as well as analyses legislative framework for land reform in all three countries.

\section{Research results and discussion}

\section{Objectives and tasks of reforms}

The conceptual task of land reforms was to rearrangement of land-based legal and economic relations. The aim was to transform legal, social and economic relationship between land ownership and land use both in rural and urban areas. Analysing the laws adopted at the beginning of land reform in each country and determined objectives and tasks, it can be concluded that in all three Baltic States specific rules were adopted to initiate land reform and to establish its main principles.

In Estonia, land reform was defined as part of the ownership reform. As the first Act can be mentioned "Principles of ownership reform in Republic of Estonia" adopted on 13 June 1991, which sets out the principles, objectives, content, of property reform, subject matter and modalities of ownership reform. This Act also forms the basis for other legislation necessary for property reform. It focuses on the return of illegally disposed real properties in 1940 (Eesti Vabariigi omandireformi..., 1991). That law was followed by the Land Reform Act adopted on 17 October 1991 (Table 3).

There was quite similar situation also in Lithuania. In 1991, two laws which provided for significant redeployments in the management of land resources in the Republic of Lithuania were adopted (Del pilieciau nuosavybvs..., 1991; Law on Land Reform, 1991). The first of these documents established general arrangement for return of ownership rights to former owners, and second law - general rules for land reform in cities and rural areas of Lithuania (Table 3).

In Latvia, unlike Estonia and Lithuania, at the beginning of reform, two parallel reforms were practically in place. Each of them was governed by separate laws. Decision of Supreme Council of the Republic of Latvia on agrarian reform can be considered as the beginning of the land reform in rural areas of Latvia (Par agraro reformu..., 1990). Land reform was planned as part of agrarian reform. Soon this decision was followed by the Law "On land reform in rural areas of the Republic of Latvia" adopted on 21 November 1990 and two years later by the Law "On Privatisation of Land in Rural Areas" adopted on 3 July 1992. Land reform in urban area cities started one year after rural 
reform with adoption of the Law "On land reform in the cities of the Republic of Latvia" adopted on 20 November 1991 (Table 3).

\section{Legislative base, objectives and tasks of the land reform in Estonia, Latvia and Lithuania}

\begin{tabular}{|c|c|c|}
\hline Countries & $\begin{array}{c}\text { Legislative base of land } \\
\text { reform }\end{array}$ & Statutory main objectives and tasks of land reform \\
\hline Estonia & $\begin{array}{l}\text { Republic of Estonia Principles of } \\
\text { Ownership Reform Act } \\
(13.06 .1991) \\
\text { Land Reform Act (17.10.1991) }\end{array}$ & $\begin{array}{l}\text { - to restore private ownership rights to the land, correcting the } \\
\text { injustice created by the illegal expropriation of land; } \\
\text { - to respect the legitimate interests of existing land users } \\
\text { - to establish pre-conditions for more efficient land use } \\
\text { - to establish pre-conditions for transition to market economy }\end{array}$ \\
\hline Latvia & $\begin{array}{l}\text { Resolution of the Supreme } \\
\text { Council of the Republic of Latvia } \\
\text { "On Agrarian Reform" } \\
(13.06 .1990) \\
\text { Law "On Land Reform in the } \\
\text { Rural Areas of the Republic of } \\
\text { Latvia" ( } 21.11 .1990) \\
\text { Law "On Land Privatisation in } \\
\text { Rural Areas" (03.07.1992) } \\
\text { Law "On Land Reform in the } \\
\text { Cities of the Republic of Latvia" } \\
\text { (20.11.1991) }\end{array}$ & $\begin{array}{l}\text { In process of gradual denationalization, conversion, } \\
\text { privatization of state property and return of illegally alienated } \\
\text { land reorganize the legal, social and economic relations of land } \\
\text { use and land ownership both in rural and urban areas for: } \\
\text { - to promote the restoration of traditional lifestyles } \\
\text { - to ensure the protection and management of natural and } \\
\text { other resources } \\
\text { - to ensure the preservation and improvement of soil fertility } \\
\text { - to expand the production of high-quality agricultural products } \\
\text { - to ensure urban development in accordance with public } \\
\text { interest }\end{array}$ \\
\hline Lithuania & $\begin{array}{l}\text { Law "On the procedure and } \\
\text { conditions for restoration of } \\
\text { property rights of citizens to } \\
\text { existing real property" } \\
\text { (18.06.1991) } \\
\text { Law "On Land Reform" } \\
(25.07 .1991)\end{array}$ & $\begin{array}{l}\text { - to ensure the protection of natural resources } \\
\text { - to implement the right of people to acquire land in property } \\
\text { and use it in accordance with the procedures specified by law } \\
\text { - return illegally expropriated land to former owners } \\
\text { - to transfer the land free of charge or for payment to persons } \\
\text { wishing to obtain it } \\
\text { - to assign State land for leasehold } \\
\text { - to establish legal and economic conditions for development of } \\
\text { national agricultural land market }\end{array}$ \\
\hline
\end{tabular}

Source: author's calculations based on land reform legislation

Analysing the objectives and tasks of land reforms defined by law, it can be found that there is no significant difference between Baltic States, little difference has been discovered in the wording of main objectives. In all three countries as main tasks of land reform restoration of private property, return of illegally nationalised 50 years ago land, as well as respect of interests of existing land users have been mentioned. The laws of Estonia and Lithuania emphasise creation of legal and economic conditions for development of land market, but laws of Latvia more focuses on social issues - need for restoration of traditional lifestyle in rural areas and achievement of high quality agricultural products, as well as formation of urban environment in interests of society. All three countries also focus on the protection of natural resources and rational and efficient use of land as one of essential objectives of the reform (Table 3 ).

\section{Progress and procedures of land reform}

Until land reform, all land resources in the territory of Latvia, Lithuania and Estonia were suborned under national jurisdiction, but as result of various processes of land reform it became as private 
ownership of natural and legal persons, municipal or state authorities. Although procedural course of land reform in mentioned states differed, all measures could be divided into four main directions, results of which are illustrated in Figure 1.

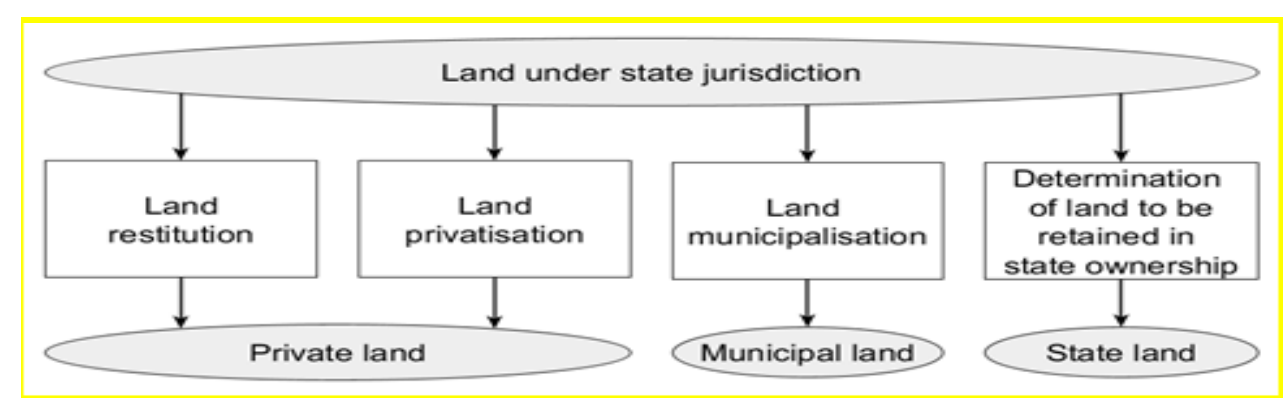

Source: developed by author's based on legislative acts

Fig. 1. Main measures in frame of land reform

One of priority tasks in land reform legislation in all three countries was to correct injustice, return land ownership rights to former owners or their heirs. According to the legislation in Estonia and Lithuania, the first step was the return of land to the former owners, followed by privatisation of land - granting of land ownership rights for payment to the interested natural and legal persons. Subsequently, further the issues of land transfer to municipal and state ownership were solved. In Latvia, unlike Estonia and Lithuania, particularly in rural areas, the reform was carried out in two steps:

- in first stage (1990 - 1996) the land was assigned for permanent use;

- in second stage (period of 10-15 years, started in 1993) the land was transferred to ownership (Zemes reformai Latvija..., 2000).

At the first stage, land for use could be requested by any person - former owner, existing land user and another person, as well as the local government and state institution. Priority was given to former landowners, except in cases specified by law. At the second stage, the land allocated for use was assigned for ownership. Decisions on restoration of land ownership rights and assignation of land in use in each country were taken by city municipality and local municipality, but the way to this decision was different in each country. Implementation of the reform in Estonia was delegated to local authorities, while for solving of specific issues were established committees, which examined applications, compensation issues etc. Land commissions at three levels (central, regional and local) were created in Latvia for the implementation of land reform. Local land commissions examined applications and made preliminary decisions on assignment of land primarily for use and further for ownership. In Lithuania land reform on regional level was organised by Agriculture Council of Ministry of Agriculture, but on local level - by specifically established services of agrarian reform.

In Latvia and Lithuania, decisions on assignation of land were made on the basis of specific projects - land survey projects, especially in rural areas. One project covered area of one former large agriculture enterprise. The projects were drafted on the base of applications of people. The Law also prescribed development of land survey projects also in cities and towns of Latvia, but in Lithuania there were developed detailed plans and land parcel development plans. In Latvia and Lithuania, the Law prescribed procedures (continuity) how to make decision, if there were two or more applicants to the some area. However, in Estonia land survey projects were not developed, boundaries of allocated land parcels were depicted on the map, which served as base of cadastre map.

There should be noted that in case of restoration of former ownerships should be taken into account the situation of 50 years under soviet system and is not necessarily to respect the boundaries 
of former land parcels, but new properties should be formed as rational land units. Former owners often demanded to restore land strictly in former boundaries, creating conditions for inefficient land use.

In all three countries, the legislation prescribed compensation (in privatization certificates) to former landowners if they were unable or unwilling to restore land ownership.

After decision making by Land commission, followed land survey process and registration of newly formed properties into cadastre information systems and legal registers, which also were created in the course of the land reform.

\section{Results of land reforms}

Although completion of land reform has not been announced yet in any of three countries, however the main tasks of land reform in Estonia, Latvia and Lithuania have been fulfilled - by 2019 in Lithuania and Latvia the majority of land ( $93 \%$ and $92 \%$ respectively) has been registered as ownership, while in Estonia this rate is less $-57 \%$. Analysing land properties according to property status, it can be concluded that largest area of land was transferred to private ownership in Lithuania and Latvia ( $89 \%$ and $71 \%$ respectively), and majority of this land is owned by natural persons. In Estonia, compared to other two countries, private ownership is limited to $60 \%$ of land properties, at the same time significantly higher proportion of land is owned by public authorities (Table 4).

Table 4

Breakdown of owned land in Estonia, Latvia and Lithuania on 01.01.2019, \%

\begin{tabular}{|l|c|c|c|}
\hline \multicolumn{1}{|c|}{ Property status } & Estonia & Latvia & Lithuania \\
\hline Owned by physical persons & \multirow{2}{*}{58} & 51 & 75 \\
\cline { 1 - 4 } Owned by legal persons & & 20 & 14 \\
\hline Owned by municipalities & 1 & 2 & 1 \\
\hline Owned by the state authorities & 41 & 27 & 10 \\
\hline
\end{tabular}

Source: author's calculations based on date of information system of national land cadastre Estonia, Latvia and Lithuania

Analysing the results of the land reform published in monographs (Aleknavicius P., 2008; Zemes reforma - atslega..., 2012) and scientific publications (Jurgenson, E., 2016, etc.) and taking into account the experience of authors of the article, the authors have summarised a number of similarities in the progress and results of the Estonian, Latvian and Lithuanian land reforms.

1) In all three countries land reform has not been lasted accomplished according to the deadlines.

The reasons for this are similar - when the reform was initiated, the organisers did not understand complexity of the process and extent of the works to be carried out. Due to long process, changes in policy frameworks led to variety of contradictions between different interests, leading to frequent amendments to laws and other legislative acts. These amendments on the one hand gradually improved land reform legislation, but on the other hand, led to some confusion for both their performers and new landowners.

2) At the beginning of the land reform there were shortages of specialists in land use planning and surveying. As necessity of cadastral surveying increased very fast, in this process were involved people who did not have such knowledge and skills. It worsened quality of cadastral surveying works; therefore mistakes arose in cadastral and legal registers. It is very important to mention that in first years of land reform in all three countries there were not established national geodetic systems, there was lack of optic and digital geodetic instruments, and therefore it was impossible to obtain accurate field survey data. Consequently, simple geodetic methods and photomaps were 
applied for allocation of land parcel boundaries. Local and free coordinate systems were also used carrying out for instrumental surveying of boundaries. National geodetic network for cadastral surveying was used only in the late 1990-s, when large amount of the land already was measured.

3) As one of the shortcomings of the reform in all three countries has been noted that in land reform laws (in Latvia and Lithuania) and in Land Consolidation Act (in Estonia) there was an obligation for forming new land parcels on land survey project to respect requirements of rational land use. However, in practice it did not really happened. The land of former owners or their heirs mainly was returned within former boundaries, by not taking into account the changes that had raised as a result of amelioration and other measures. Often this led to embarrassing, impractical spatial structure of ownership in rural areas, but in urban areas - to the properties where landowner and owner of buildings were different persons.

4) Agricultural reform usually is one of the means of restructuring agriculture. However, existing land reform was not aimed to establishment of prospective agricultural enterprises, but to restoring justice in rural areas. In any of of the analysed countries, the legislation on land reform did not specify minimum area of land. Only the maximum areas for payment were defined. Consequently, very fragmented structure of land parcels has been developed in rural areas. In all three countries the average total area of land parcel allocated to natural and legal persons, according to the data of the Cadastre information systems, is 8 ha (data on 01.01.2018). By the way, large area of the land was assigned to people who didn't use this land. Due to small areas of land and also because landowners live remotely (far from his land) it was impossible to establish individual household and they are forced to rent out or sell the land (Aleknavicius P., 2008). Although the majority of rural residents buy the land, due to deterioration of agricultural conditions, loss of jobs, emigration etc., the population in rural areas has decreased in all three countries.

\section{Conclusions, proposals, recommendations}

1) Decisions taken at the end of the 1980-s on creation of peasant farms in Estonia, Latvia and Lithuania played an important role in future land reform processes. The high demand for land, although the land remained in state ownership, created preconditions and experience for drafting of land reform legislative acts.

2) After analysis of the objectives of land reform and its implementation the authors made a conclusion that, in general, the main result in all three countries has been achieved - the land is returned for ownership to citizens of Estonia, Latvia and Lithuania, the right of people to acquire land has been exercised, as well as conditions for development of land market have been established. There can be critically discussed results of land reform focused on more efficient land use (in Estonia) or to ensure of rational use and protection of natural resources (in Lithuania) as well as restoration of traditional rural lifestyle (in Latvia).

3) For the first time, land reform in Estonia, Latvia and Lithuania covered the entire territory of country. It greatly increased amount and complexity of work, and affected the period of processes. The land reform created the related legal environment in all spheres of life. Not all laws, decisions and regulations were substantially evaluated or could not be foreseen and not all decisions led to the expected outcome. A great amount of responsibility had been delegated to local municipalities regarding decision making, although not all municipalities were prepared to deal with land issues. 
Voluminous land reform activities faced with a lack of surveying and land management specialists, survey instruments etc.

4) In privatising the land, in rural areas of Latvia the principle "to property through land use" was observed. It ensured gradual privatisation of land as well as a more justified subdivision of land. This also showed that in fact not everyone who had applied land for use, privatised it in further course of reform. Such principle does not existed in Estonia and Lithuania. However, it should be noted that there are no significant differences in the results of the reform in Estonia, Latvia and Lithuania, the average total area of land parcel in rural areas in all countries is equal to 8 ha.

5) As positive moment in result of the land reform, it should be noted that modern system of cadastre and legal register was established and implemented in all three Baltic countries.

6) Although no one of the three Baltic States has declared on completion of land reform yet, after analysing results of land reforms it should be concluded that the next phase of the "land reform" needs to be carried out. Changing legislative acts should be planned measures of land consolidation or land use planning, in order to eliminate shortcomings that appeared during the reform and create conditions for rational land use, to eliminate the fragmentation of land and other disadvantages.

\section{Bibliography}

1. Aleknavicius P. (2008). Zemes santykiu pertvarkymas Lietuvos kaime 1989-2008 metais: monografija (Transformation of Land Relations in Lithuanian Village 1989-2008: monograph). Vilnius: Jandrija. pp. 447.

2. Auzins, A. (2008) Zemes parvaldibas pamati (Basics of Land Management). Riga: RTU Izdevnieciba. p. 106.

3. Del pilieciu nuosavybes teisiu i islikusi nekilnojamaji turta atstatymo tvarkos ir salygu. Istatymas (1991). (Regarding the procedure and conditions for the restoration of the citizens' property rights to the existing real estate. The law) 199106 18; Nr. I-1454. Valstybes zinios, 1991, Nr. 21-545.

4. Eesti NSV taluseadus (Farm Act of the Estonian SSR) (1989). Vastu voetud 6.12.1989. Retrieved: https://www.riigiteataja.ee/akt/30680. Access: 15.01.2020.

5. Eesti Vabariigi omandireformi aluste seadus (Republic of Estonia Principles of Ownership Reform Act) (1991). Vastu voetud 13.06.1991. Retrieved: https://www.riigiteataja.ee/akt/112122018009. The English version is available in: https://www.riigiteataja.ee/en/eli/ee/520122018006/consolide/current. Access: 15.01.2020.

6. Jurgenson, E. (2016). Land reform, land fragmentation and perspectives for future land consolidation in Estonia. Land Use Policy, 57, 34-43.10.1016/j.landusepol.2016.04.030.

7. Maareformi seadus (Land Reform Act) (1991). Vastu voetud 17.10.1991. Available at: https://www.riigiteataja.ee/akt/112122018015. The English version is retrieved in: https://www.riigiteataja.ee/en/eli/520122018008/consolide

8. Par agraro reformu Latvijas Republika (1990). Latvijas Republikas Augstakas Padomes lemums, 13.06.1990. (Resolution of the Supreme Council of the Republic of Latvia On Agrarian Reform). Retrieved: https://likumi.lv/doc.php?id=76206. Access: 17.01.2020.

9. Par zemes privatizaciju lauku apvidos (1992) (Law On Land Privatisation in Rural Areas), Latvijas Republikas likums, pienemts: 03.07.1992. Retrieved: https://likumi.lv/ta/id/74241-par-zemes-privatizaciju-laukuapvidos. The English version is available at: https://likumi.lv/ta/en/en/id/74241-on-land-privatisation-inrural-areas. Access: 15.01.2020.

10. Par zemes reformu Latvijas Republikas lauku apvidos (1990) (Law On Land Reform in the Rural Areas of the Republic of Latvia) LR likums, pienemts 21.11.1990. Retrieved: https://likumi.Iv/ta/id/72849-par-zemesreformu-latvijas-republikas-lauku-apvidos. The English version is available in: https://likumi.Iv/ta/en/en/id/72849-law-on-land-reform-in-the-rural-areas-of-the-republic-of-latvia. Access: 17.01.2020.

11. Par zemes reformu Latvijas Republikas pilsetas (1991) (Law On land reform in the cities of the Republic of Latvia) LR likums, pienemts 20.11.1991. Retrieved: https://likumi.lv/ta/id/70467-par-zemes-reformulatvijas-republikas-pilsetas. Access: 17.01.2020.

12. Par zemnieku saimniecibam Latvijas Padomju Socialistiskaja Republika (The Law On peasant farms in Latvian Soviet Socialist Republic) Latvijas PSR likums (1989). Latvijas PSR Augstakas Padomes un Valdibas Zinotajs, 18.05.1989, Nr. 20.

13. Zemes reforma - atslega uz ipasumu, 1990 - 2012 (2012) (Land reform - the key to real property, 1990 2012), zin.red. J. Mierkalne Riga, LR Valsts zemes dienests. 335 c.

14.Zemes reformai Latvija 10 gadi 1990 - 2000 (2000) (Land reform in Latvia 10 years 1990 - 2000) atb. red. J. Blite. Riga, Valsts zemes dienests. P. 160.

15. Zemes reformos istatymas (Law on Land Reform) (1991a) - 1991-07-25; Nr. I-1607. Lietuvos aidas, Nr. 151. 